\title{
Allan H. Meltzer
}

Allan H. Meitzer is a professor of political economy and public policy at Camegie Mellon University and a visiting scholar at the American Enterprise Institute. Thanks to Craig Hakkio, Carl Christ and Bennett McCallum who commented on an earlier draft and to Jeffrey Liang who contributed more than the usual assistance. A preliminary version was presented at the 1992 Western Economic Association session honoring Miton Friedman on his 80th birthday.

\section{Real Exchange Rates: Some Evidence from the Postwar Years}

T early in 1973 is the type of experiment that economic researchers experience rarely. A marked change in monetary regime from fixed to flexible rates was followed by years of floating rates. Initially, some governments may have thought of flexible rates as a temporary expedient to last only until new parities were firmly established. Within a few years, however, the governments of principal developed countries, including the United States, accepted flexible rates as a durable arrangement. Although there has been considerable intervention in the currency markets, attempts at policy coordination and talk about target zones (particularly in recent years), the dollar and several other currencies have continued to float. Most major trading countries have reduced or removed exchange controls and other restrictions on capital mobility.

A frequent, and probably the dominant, assessment of experience with flexible rates is that they have not worked as anticipated. Robert Aliber (1992, p. 44) writes that "Few of the advantages noted by proponents of floating exchange rates have been realized in the 1970 s and the 1980s." Krugman and Miller $(1992$, p. 1) share this view and in addition, criticize theories of exchange rate determination. They write that "interventionist economists believed that left to themselves exchange markets would introduce unnecessary and harmful volatility into the exchange rate." These writers summarize the current state of research as showing that monetary models "have had almost no empirical success. Indeed, money supplies, if they enter at all, typically enter with the wrong sign." (ibid, p. 9)

Singleton (1987, p. 9) reports the professional judgment that "by most measures, exchange rates have been relatively unstable since 1973 ." He recognizes, however, that the instability may reflect uncertainty that the public faces in adjusting to information about the future. And he notes that observed variability of exchange rates may have lower welfare costs than altemative regimes.

Mussa (1986) studied fluctuations in bilateral exchange rates for the principal market economies. He showed that the variability of bilateral real exchange rates from 1957 to 1984 was eight to 80 times higher in flexible-rate periods. There were no examples of lower variability under flexible rates among the 17 countries studied. The reason is clear from Mussa's data. Under flexible exchange rates the variability of nominal exchange rates increases much more than the variability of the ratio of relative price levels declines. In fact, the variance of bilateral rela- 
tive price levels was not always lower in flexiblerate regimes.

Mussa did not draw any conclusion about the welfare properties of alternative regimes. The increased variance of bilateral real exchange rates may substitute for the variance of other variables, may be absorbed at relatively low cost by hedgers and speculators in financial markets, or in part may represent permanent shocks, such as the oil shocks of the 1970 s and 1980 s, that require adjustment of relative prices and real values. But the alternative is also plausible. Some of the higher variances under fluctuating rates may be the source of excess burden.

A main problem in reaching a judgment about the operation of fluctuating rates is that there is no benchmark for comparing altemative regimes. Economic models of exchange rates have performed poorly compared with statistical models such as the random walk. Many papers report that there is no significant relation, of ten no evidence of any reliable relation, between exchange rates and other economic variables. Meese and Rogoff's (1983) well-known paper found that a random walk performed as well out of sample as any estimated structural model. This suggests that many changes in exchange rates are random events, unrelated to policy or macroeconomic performance. Chinn (1991) summarizes recent tests for cointegration of real and nominal exchange rates with standard economic aggregates such as money and output at home and abroad or, for nominal exchange rates, realive rates of inflation. The tests reject contegration, suggesting that there is no long run relationship between exchange rates and any of these aggregates.

Critics have commented especially on the relatively large change in dollar exchange rates in the 1980s. Even Haberler (1987), a long-time proponent of Hoating refers to "the widespread disenchantment with floating exchange rates." Critics have not been satisfied with computations showing that the variances of exchange rates, like the prices of other traded assets, exceed the variances of prices of current production. Nor have they accepted as sufficient explanation for observed variability that foreign exchange markets, like other markets for traded assets, respond to new information, which arrives continuously in a changing world. "Without evidence showing that the news is systematically linked to exchange rate changes and that the adjustments are toward a new equilibrium, the proposition is nearly empty. ${ }^{2}$

A longer summary of the large literature on flexible rates would belabor the obvious. Neither the critics nor the proponents of flexible exchange rates have produced much evidence on which to base comparative judgments about exchange rate regimes. Claims that variability is larger or too large are meaningless unless an alternative is specified and its properties compared. Yet it is common to find statements that flexible rates have not worked as expected. They "do not substantially shield a country from events abroad"; that "current account imbalances have been protracted", and that "wide movement and reversals have contributed to the widespread impression that floating rates tend to overshoot." "Although clean floating has not yet become a dirty word, the simple faith that the market is always right has been shaken." 3

This paper reconsiders experience under flexible exchange rates. Section 1 summarizes the claims about flexible rates in Milton Friedman's classic 1953 paper to show that Friedman's claims are more modest than is often supposed. Section 2 presents some key facts about exchange rates and comparative variability of several variables under fixed and flexible rates. Section 3 estimates a model of the so-called real exchange rate under Bretton Woods and flexible rates and tests for the effect of economic aggregates on the exchange rate. The model incorporates some of the principal variables affecting exchange rates suggested by friedman. Section 4 discusses some limitations of the results. A conclusion completes the papes.

\section{FTREMMAN'S CASE FOP FLEXIBLE EXCTINGE TITIRS}

In "The Case for Flexible Exchange Rates," written shortly after the Bretton. Woods System started, Friedman claims four benefits for flexible rates: (1) increased liberalization of trade, (2) avoidance of direct controls, (3) facilitation of

See Frenkel (1983).

27he qualification is needed because some testable propositions result. Changes may be unbiased or targer in periods of large shocks such as wars and oil price changes.

asee Wallict (1984) 
rearmament, and (4) harmonization of internal monetary and fiscal policies. ${ }^{4}$ The point that concerned later critics most, variability or insta bility, is dismissed early with the claim that exchange rate instability reflects instability in the economy and is not a property of a flexible or floating rate system. This claim is not selfevident, and it has not been accepted by the principal critics of flexible rates. Friedman appears to have anticipated this outcome. He devotes more space to refuting or dismissing the charge of instability than to making the positive case for the four benefits claimed for flexible rates.

Friedman's essay does not clam that flexible exchange rates are optimal for all countries or even for a single country. When discussing the fomer sterling bloc, he considers a mixed system in which groups of countries may elect to maintain fixed exchange rates internally and flexible rates against all other groups or coun. tries. Although there are structural differences between the sterling bloc and the proposed European Monetary Inion, Friedman anticipates the principal issues: policy harmonization, avoid. ance of trade controls and exchange restrictions, absence of a political authority and, in the absence of controls, the need to choose between unemployment and exchange rate changes in the short term.

Recognizing that optimality of flexible rates cannot be established, Friedman limits his claim to the judgment that flexible exchange rates are more desiable socially than the four alternative means of offsetting changes in international position. The four alternatives are: (1) official changes in currency reserves; (2) changes in domestic price levels and incomes; (3) periodic realignment of parities; and (4) direct controls.

The key conditions are posited. First, with llexible exchange rates, there are "broad, active, and nearly perfect markets ... in foreign exchange" whenever they are permitted. Second, a fixed but adjustable exchange rate "insteres a maximum of destabilizing speculation. Because the exchange rate is changed infrequently and only to meel substantial difficulties, a change tends to come well after the onset of difficulty, to be postponed as long as possible." These condtions, it seems fair to say, have not been accepted by the critics of flexible rates. The critics typically argue that speculation is (or can be) destabilizing.

Friedman considers and rejects some common conjectures about destabilizing speculation. His main argument is that there is no empirical foundation for these claims. Appearances to the contrary are misleading and subject to misinterpretation. A main problem in any study is to separate the actions of speculators based on correct predictions of parity changes and actions that cause parity changes that would have been avoided. These problems arise under an adjustable peg, but Friedman claims they would be prevented under continuous adjustment of flexible rates. Friedman is cautious, however. He avoids a general claim that speculation is stabilizing. Instead, he argues that if destabilizing speculation is common, governments (or exchange stabilization funds) would profit by intervening. And he recognizes that governments may have move information or mone timely information that gives them an advantage over private speculators. He is willing to let a government agency intervene to smooth temporary fluctuations if they can do so profitably (p. 188), but he is skeptical that they would be able to profit consistently. They are less likely to profit, he claims, than private speculators who risk their own wealth.

The reason for choosing flexible rates is that other means of adjustment are less satisfactory. Fixed exchange rates were maintained in the 19 th century because the public and governments tolerated larger fluctuations in domestic prices and employment than would be acceptable in the late 20th century. Direct controls are least satisfactory because they introduce distor. tions and do not correct permanent differences in relative prices in foreign and domestic markets.

Timing of adjustments is a source of variability about which little is known with precision. Anticipating future discussion, Friedman considers overshooting and undershooting of exchange rates. Overshooting arises because initial adjustment is borne by prices that adjust most readily. The exchange rate is such a price. Later other prices adiust, and the overshooting reverses. although it may be replaced by undershooting of the final change, followed by a series of adjustments around the new equilibrium.

4The essay was written in 1950 but not published until 1953 .

5 See Friedman (1953), pp. 162-64. 
Thus Friedman recognizes that there will be variability and fluctuations of exchange rates, not prompt, rapid adjustment from the old to the new equilibrium. The possibility that the fluctuations, though not destabilizing, produce excess burden and welfare loss is not addressed directly. Friedman's matn response to this central issue is comparative. His conclusion can be sum. marized in two paragraphs.

First, comparison of exchange rate regimes must include the costs of adjustment under alternative policies. The comparison cannot be linited to the size of changes in exchange rates or the varability of exchange rates under different regimes. Changes in the relative prices of goods and services are not the same under different policies. With gradual adjustment of real wages and other relative prices, labor market adjustment, hence unemployment rates, will differ under different regimes. And direct controls infroduce distortions and welfare losses.

Second, there is no presumption that social costs could not be increased by flexible exchange rates. "About all one can say ... is that there seems no reason to expect the timing or pace of adjustment under the assumed conditions [flexible exchange ratesl to be systematically biased in one direction or the other from the optimum or to expect that other techniques of adaptationthrough internal price changes, direct controls, and the use of monetary reserves with rigid ex. change rates-would lead to a more nearly optimum pace and timing of adjustment." 6

\section{EXCHANGE RATE CHANGES AND VARIABILITV, $1973-90$}

Excessive variability is one of the main issues raised by the critics of flexible rates. Evidence of increased variability of real or nominal ex- change rates after 1973 is easy to produce. To draw any conalusion about the effects on welfare, two issues must be resolved. First, as Friedman noted, increased variability of exchange rates may reduce variability of output, consumption, employment or other variables of interest to consumers. Reduced variability of these variables can produce a welfare gain despite the increased variability of exchange rates. Second, increased variability of exchange mates may result from real shocks, such as an oil shock, or from policy activism, or it may reflect increased knowledge of the operation of exchange markets.

This section considers changes and variability of exchange rates and some other variables under Bretton Woods and flexible rates. Figure 1 shows the monthly trade-weighted nominal and real exchange rate for the United States, using Federal Reserve weights, for the period 1973-90. A rise in the index is an appreciation of the dollar. Two facts are immediately apparent. First, real and nominal exchange rates move together and by similar amounts. This fact has been demonstrated repeatedly for biateral rates. See Mussa (1986) and Edwards (1989) for studies of developed and developing countries. Second, trade-weighted exchange rates moved over a relatively wide range during the 18 year period. The movement is dominated by a persistent appreciation from 1980 to 1985 followed by a persistent deprecia lion lasting to early 1987 . Both exchange rates then refurned to approximately the same range they had left in 1979 .

Other measures of trade-weighted exchange rates developed by the International Monetary Fund (IMF) using wholesale prices or unit labor costs in the various countries to compute real exchange rates show the same general pattern. Experiments with different weighing patterns

SSee Friedman (1953). The conflicts in the system developed more slowly than Friedman predicted. He predicted that "direct controls over exports and imports would be feimposed on a large scale within two or three years at the most." This prediction was inaccurate. The United States introduced some controls on capital movements in the 1960 s, but the trend in the 1950s and 1960 s was toward reduction of Irade bartiers under General Agreement on Tariffs and Trade rules. The conficts in the syssem were resolved party by changes in parities abroad but mainly by inflation in the 1960 s and early 1970 s.

${ }^{7}$ The so-called real exchange rate measures the ratio of the price level in the United States to a weighted average of foreign price levels expressed in a common currency. 
Figure 1

Trade-Weighted Nominal and Real Exchange Rates

Index $(1973: 3=100) \quad$ Monthly $1973: 1$ to $1990: 12$

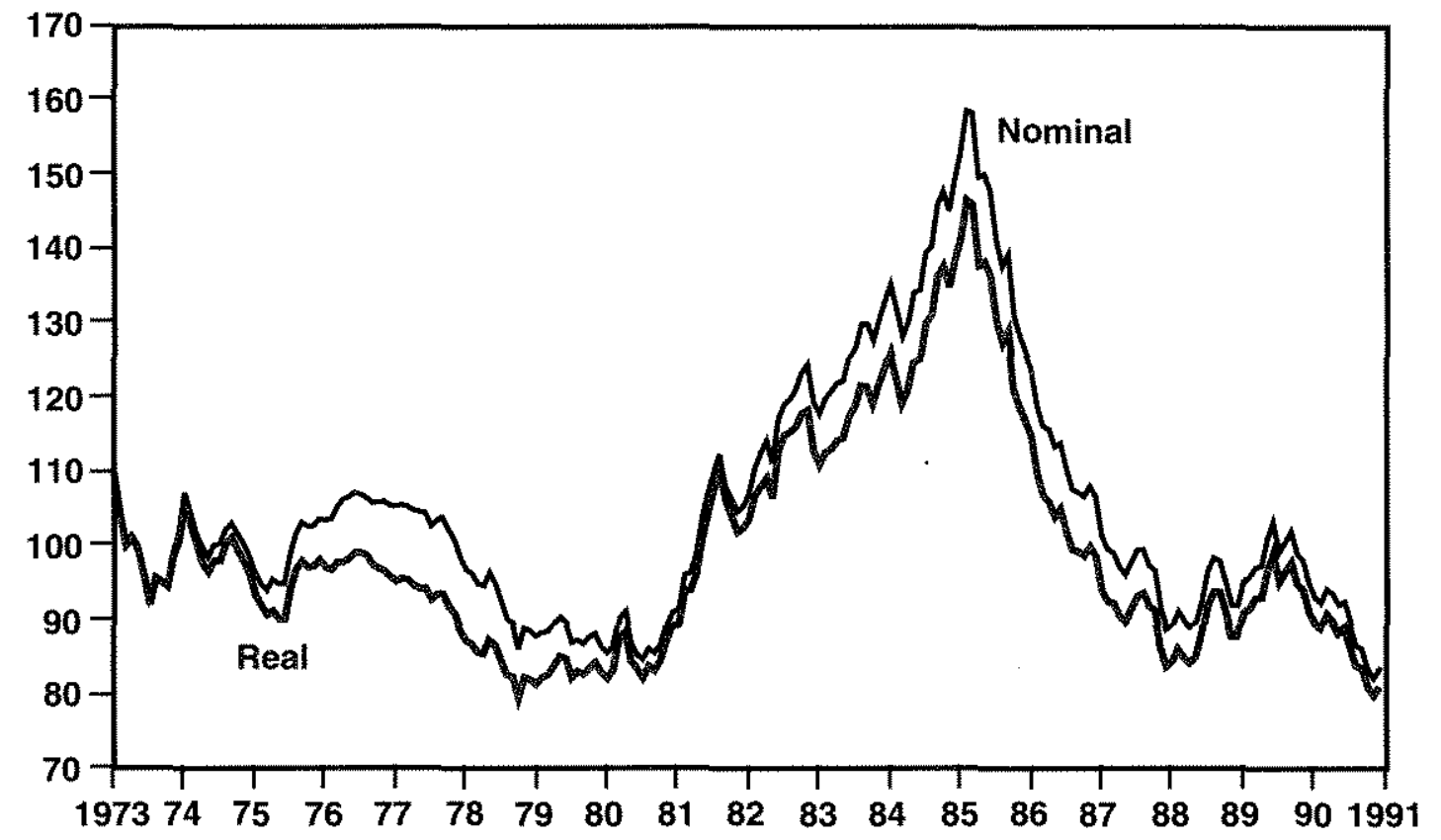

do not appear to change the general features, athough computed variances and ranges differ for the individual measures. ${ }^{8}$

The exchange rate data shown in figure 1 raise two issues that will concern us. First, why do real and nominal exchange rates move together? Second, is the higher variability of real exchange rates under fluctuating exchange rates caused by policy actions, on is there evidence of excess burden arising from increased variablity unvelated to policy action?

The similarity of real and nominal exchange rate changes in figure 1 is not peculiar to U.S. data. Figure 2 shows monthly values of the exchange rate of the Japanese yen for the German mark during the period 1973-90. The real exchange rate is obtained using the relative con- sumer price indexes for the two countries. In the first years, the real and nominal exchange rates differ; consumer prices rose more rapidly in Japan than in Germany. In real terms Japan paid more yen per mark than in nominal terms. After 1976, the two price levels had about the same rate of change, so the real and nominal exchange rates are often indistinguishable on figure 2 .

Mussa's (1986) study of changes in bilateral exchange rates for a broad sample of developed countries during the years 1957-1984 found the same result. Inder flexible exchange rates, changes in nominal and real exchange rates are highly correlated, but changes in nominal or real exchange rates are not closely comelated with changes in the ratio of price index numbers.
${ }^{8}$ Becketti and Hakkio (1989) computed the correlation between innovations in seven alternative measures of trade-weighted exchange rates. Most of the correlations are above 0.9 using quarterly data for 1976 to 1988 . They show that simifar results hold for percentage rates of change of exchange rates.

The Federal Reserve index uses weights reflecting country shares of world trade. I computed an alternative index based on $U . S$. trade welghts and reweighted the index at the start of each decade-1960, 1970 and 1980-10 adjust for changes in relative trade shares. The main conclusion sensitive to the change in weights is that the variance of the trade-weighted real exchange rate is lower for the alfemative measure. I have used the Federal Feserve index throughout. 


\section{Figure 2 \\ Real and Nominal Yen/DM Exchange Rates}

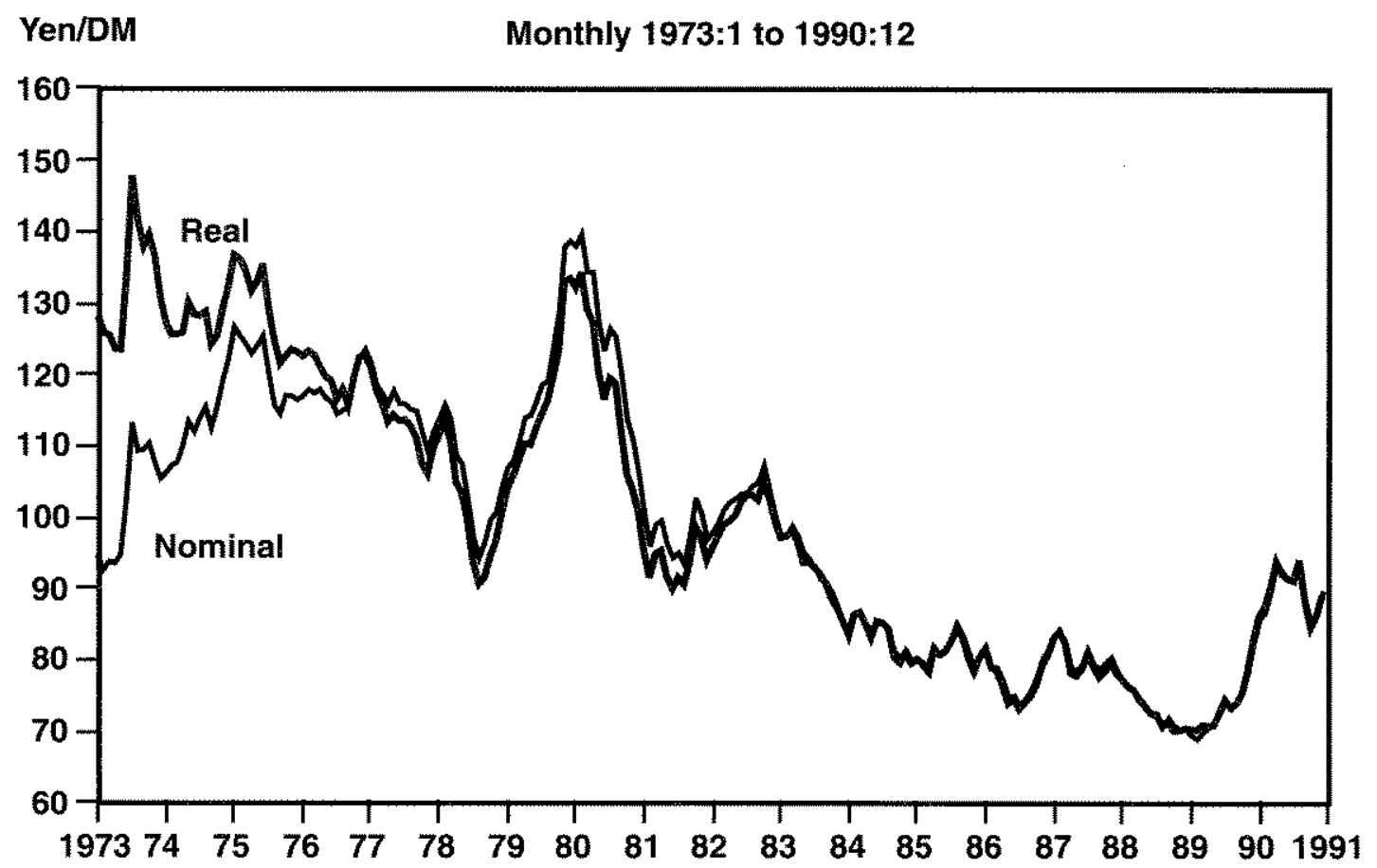

Meltzer (1990) considered the variability of multilateral exchange rates using data from the IMF. Real exchange rates are based on both relative wholesale prices and relative unit labor costs, and variances are used to measure variability. Again, countries with flexible exchange rates had greater variability of nominal and real exchange rates than countries in the European Monetary System (EMS) that mantained an adjustable peg with other members of the EMS. Changes in real and nominal exchange rates were highly correlated under flexible rates. How ever, the variability of relative unit labor costs was typically lower in the countries with flexible exchange rates, whereas the variability of wholesale price ratios was higher.

Table 1 summarizes these data. Both nominal (N) and real (B) exchange rate changes are more variable under flexible exchange rates than under fixed but adjustable rates, whereas relative prices are not. The variability of $R$ or $N$ under flexible rates is significantly different at the 1 percent level from the variability experienced under EMS or the mixed regimes (denoted other) that had crawling pegs or some other type of partially fixed nominal exchange rate during this period. Changes in multilateral real exchange rates are 4 or 5 times more variable in flexiblerate countries than in the EMS. Generally, the variances for "other" countries lie between the variances for the EMS and flexible-rate countries. The exception is $p_{t c c}$ - the variability of changes in relative prices based on unit labor costs, $P_{\text {pin }}$ has been lower on average under flexible rates, although the difference between regimes is not significant by the usual standards.

The much-discussed increase in the variability of real exchange rates in a flexible exchange rate regime may reflect only that flexible exchange rates change more frequently, whereas the relative price ratios are not much affected by the change in regime. Using the terms of trade as a measure of relative prices, table 2 shows that the variances of relative price ratios do not differ systematically across exchange rate regimes. Variability of the terms of trade rose in all countries but to different degrees unrelated to the exchange rate regime. The comparatively high variability of Japan's terms of trade suggests that there is no simple relation between the variability of this measure and the growth of trade. 
Table 1

Variances of Changes in Relative Prices, Real and Nominal Exchange Rates 111979-111/1989

\begin{tabular}{|c|c|c|c|}
\hline 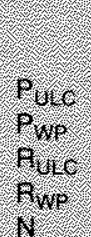 & 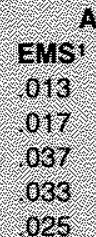 & 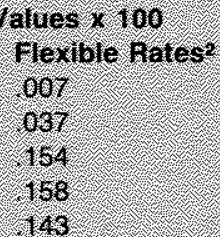 & 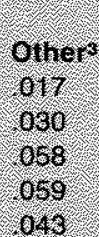 \\
\hline
\end{tabular}

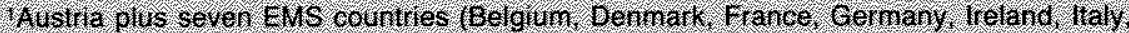
Nethertands).

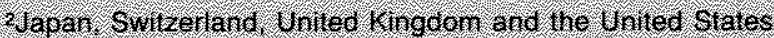

3roway soain. Sweden, F nland and Ganada

Source $\mathrm{MF}$ whete $\mathrm{N}=\mathrm{h}+\mathrm{P}$

$101 \mathrm{E}$

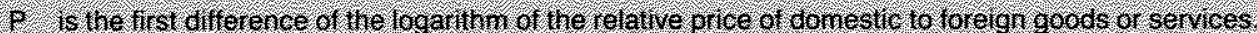

F. is the fist difference in the logarith of the reat exchange tate

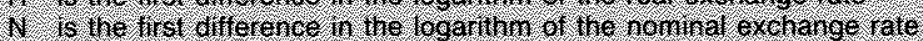

\section{Table 2}

Variances under Fixed and Flexible Rates United States, Germany, Japan and the United Kingdom (quarterly values at annual rates)

\begin{tabular}{|c|c|c|c|c|c|c|c|c|}
\hline \multirow{3}{*}{ Perrod } & \multicolumn{4}{|c|}{ Rear GNP or GDP } & \multicolumn{4}{|c|}{107} \\
\hline & U.S. & Germany & Japan & 016 & Us: & Cethany & Uapan & G. \\
\hline & 110 & 279 & 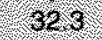 & 30.0 & 15.5 & 260 & 235 & 259 \\
\hline $1(1973 \times 117999)$ & 157 & 86 & 113 & 926 & 922 & 925 & 3900 & 626 \\
\hline Pelatve value & 1,4 & 03 & 03 & 1.1 & 59 & 06 & 16.6 & 24 \\
\hline 11973111979 & 242 & $106 \%$ & 374 & 705 & 2023 & 2852 & 2377 & 197.3 \\
\hline 111997.111080 & 197 & 7.1 & 51 & 598 & 602 & 524 & 481,1 & 408 \\
\hline $111980-1111967$ & 133 & 66 & $58^{2}$ & 106 & 61.7 & 782 & 8888 & 316 \\
\hline W/9g7-1W19g1 & 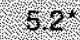 & 35 & 78 & 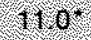 & 710 & 248 & 1706 & 276 \\
\hline
\end{tabular}

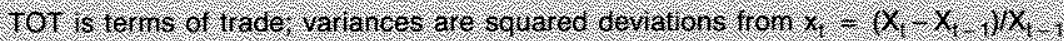

Nots. venotes that the variance is lower han under Bretton Woods.

Table 2 also compares real output variances under fixed and flexible exchange rates in four countries. There is no relation between the relative variances and the monetary system. Real ouput variability declined in the same proportion in Germany and Japan with (mainly) fixed and flexible rates respectively and rose moderately in the United States and the United Kingdom. ${ }^{9}$
The last four lines of the table show variances for subperiods. The oil shocks of the $1970 \mathrm{~s}$ increased the variances in table 2 in the early years of flexible rates. Variability of output fell in the United States in each successive period. In all countries the variance of real GDP was lower in 1987-91 than under the Bretton Woods regime.

Meltzer (1986) reports similar results for the four countries using unanticipated variances. Unanticipated variances were computed using forecasts obtained from a muttistate, univariate Kalman filter. 
The countries shown in table 2 have different exchange rate systems. Japan and the United Kingdom had flexible exchange rates during the period, athough the United Kingdom lixed to the exchange rate mechamism (ERM) of the EMS at the end of the period. Germany has been in the fixed-but-adjustable-rate ERM system since March 1979, and it experimented with other fixed-butadjustable-rate systems with its neighbors beginning in the mid-1970s. The mark fluc. tuated, however, against the dollar, yen and many other currencies.

Though the variability of Germany's output growth is, on average, lowest of the countries in table 2 , this cannot be attributed entirely to the retiance on fixed-but-adjustable rates. Variability of output growth in Germany was also lower than in Japan or the United Kingdom during the Bretton Woods period, and the rela tive decline in variability is the same for Germany and Japan. Further, during 1975-80 and 1980-87, periods of declining inflation, variability of Japan's output growth is comparable to (and even slightly below) Germany's.

The main conclusion drawn from table 2 is that there is no basis for a general proposition that output is more variable under fixed rates than under flexible rates. Relative prices (terms of trade) are more variable in all countries after 1973 , but the increase is smallest in the United Kingdom.

\section{POLICICS AND REAL EXCWANGE PATTS}

Friedman (1953) made two suggestions that have been overlooked. He gave prominence to policy-particularly rearmament-as one of the main factors affecting U.S. real exchange rates. Reamament changes relative prices and the balance of payments (Friedman, pp. 159-60). Also, Fredman distinguished permanent and trans: tory changes in exchange rates. He noted the different response of speculators to changes that were expected to reverse and those that were expected to persist. ${ }^{10}$

Real government spending for defense rose and fell during the postwar years. Spending rose during the Vietnam $W$ ar and declined dur.

10See Friedman $(1953$, p. 162). I began work on the relation of permanent and transitory fiscal and monetary changes to real exchange rates before I reread Friedman's essay. I was pleased to find that the results I had obtained provided evidence on some of his principal propositions. ing the 1970 s both absolutely and relative to real output. Spending rose again in the $1980 \mathrm{~s}$, reached a peak in the mid-1980s and declined modestly to the end of the decade. Maintained changes in the level of real defense spending act like any fiscal change. Increases in real defense spending raise aggregate spending and intelest rates. Higher interest rates attract a capital inflow, appreciating the exchange rate. In the absence of capital controls and restrictions, the capital inflow reverses the rise in the interest rate. Reductions in real defense spending have the opposite effects. ${ }^{11}$ "The sign of real defense spending per unit of output should be positive.

Real money balances also affect real exchange rates. Injections of money temporarily increase real balances, and if the price level does not adjust instantly, the increase in money depreciates the real exchange rate. Reductions in real balances brought about by reductions in money or by a rise in prices for a given quantity of money appreciate the exchange rate.

Let $r$, the real exchange rate, have a permanent and transitory component, so that

(1) $r_{t}=\bar{r}_{t}+u_{t}$

where $\bar{r}_{1}$ is the permanent component and $u_{k}$ is the transitory disturbance. In the absence of changes in defense spending, real U.S. money balances and foreign real balances, the expected value of the exchange rate is the permanent value. The current permanent value is a weighted average of last period's exchange rate and any persistent effect of defense spending (relative to GDP) and real money balances at home and abroad as shown in equation (2).

(2) $\bar{r}_{i}=\alpha r_{1 \ldots 1}+(1-\alpha) f\left(d_{1}, m_{1}, m_{1}^{*}\right)+v_{1}$

Combining equations (1) and (2) gives equation (3). a testable equation for the real exchange rate.

(3) $r_{\mathrm{t}}=\alpha r_{\mathrm{l}-1}+(1-\alpha) f\left(d_{\mathrm{t}}, m_{\mathrm{r}} m_{\mathrm{t}}^{*}\right)+\varepsilon_{\mathrm{t}}$

where $\varepsilon_{\text {, }}$ has the usual properties.

If the real exchange rate is mainly a random walk, $r_{1}=r_{1,1}$ plus a transitory white noise term.

${ }^{1}$ Defense spending is a large share of government spending on goods and services. It has the advantage of being independent of income and hence a good measure of the thrust of exogenous fiscal policy. It also permits a test of Friedman's proposition. 
Table 3

Determinants of the Real Exchange Rate* (t statistics in parentheses)

\begin{tabular}{|c|c|c|c|c|c|}
\hline & $(1)$ & $(2)$ & (3) & (4) & $(5)$ \\
\hline Perloos & $1962-91$ & 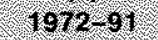 & $111971-11 / 991$ & $1960 / 91$ & $1972-91$ \\
\hline & atnuar & Annual & Quartery & Annud & Antual \\
\hline fEA & 0.60 & 0772 & 0.62 & 0.67 & 055 \\
\hline & $(6.40)$ & $(0,69)$ & $(1,76)$ & $(5.57)$ & $(3,12)$ \\
\hline $\mathrm{r}$ & 0,15 & 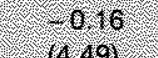 & 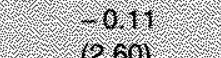 & $-0,12$ & -0.16 \\
\hline t & $\begin{array}{r}(4.45) \\
0.28\end{array}$ & $\left(\begin{array}{l}1499 \\
026\end{array}\right.$ & 0.07 & $\begin{array}{r}3871 \\
0.21\end{array}$ & 0,16 \\
\hline & 255 & $(172)$ & 10.52 & $(1.77)$ & $(106)$ \\
\hline a. & 502 & 975 & 3.37 & 5.88 & 16.02 \\
\hline & $(2,8)$ & $(1,94)$ & $(166)$ & $(2,82)$ & $(2 \times 4)$ \\
\hline constant & 5364 & 44.50 & 208 & 625 & 5280 \\
\hline & $(3.26)$ & $(245)$ & $(24)$ & $(6,6)$ & $(268)$ \\
\hline hrow & $0.80 / 189$ & 078,203 & 0.061195 & $0,86,92$ & 0771200 \\
\hline forpl & $0.09(6.66)$ & $-011(0.25)$ & $0.26(1,70)$ & $0.140 .50)$ & 0.1010 .23 \\
\hline
\end{tabular}

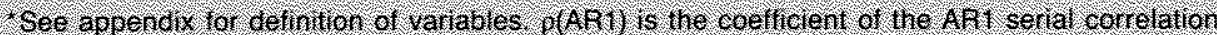
correction and its istatistic

But if monetary and fiscal actions have persistent effects, these effects will be found significant in estimates of equation (3). Equation (3) therefore permits a test of the influence of the defense spending share and real money balances against the alternative hypothesis that real exchange rates are approximately a random walk and independent of systematic monetary and fiscal effects. If the real exchange rate is mainly a random walk, $\alpha$ is close to one. If there are persistent and systematic effects of money and the defense spending share, current values of these variables will have a significant effect on the real exchange rate.

The first two columns of table 3 show estimates for 1962-91 and 1972-91 based on annual data; the former includes the fixed exchange rate period, whereas the latter does not. The two sets of estimates are similar. The standard errors of estimate for the two equations are 5.9 and 6.8 , a difference of approximately 1 percent of the mean value of the real exchange rate. The implied standard error of estimate for the Bretton Woods period is 3.6 , about half the value for the flexible rate period. These values suggest that transitory random variation increased under flexible rates, but the increase is much smaller than is commonly alleged. A main reason is that the estimates here remove the effects of permanent changes in $m, m^{*}$, and $d$. These variables, particularly real money balances, have significant effects on the trade-weighted real exchange rate.
One problem with these estimates is that the coefficient of $m_{1}^{*}$ is much larger than the coefficient of $m_{1}$ using annual data. The difference may not be meaningful, however. The definitions of money differ (as described in the Appendix), and the difference in coefficients is not significant.

Figure 3 shows the actual and predicted values of table 3 using equation (1). Many of the claims about exchange rate instability are based on the relative changes in the 1980s. The chart suggests that much of the swing in the tradeweighted real exchange rate during the 1980 s is driven by the variables in the model. The defense spending share rose by more than a percentage point in the early 1980 s then fell after the middle of the decade. Real money balances moved in the opposite direction, falling through 1982, then rising, particulariy in 1985 and 1986 . The forecasts and actual values are extremely close for 1981-83. There is some evidence of overshooting by the actual rate in 1984-85, but the errors are not much larger than the standard error of estimate. The subsequent decline in the forecast value lags the actual decline, however, in 1986 and 1987. The largest error in the 29-year span is in 1986.

The third column in table 3 shifts the time interval from annual to quarterly data. The results are similar to the annual data except that $\mathrm{m}_{r}{ }^{*}$ is no longer significant. Current real money balances remain significant at the usual level, and the defense spending share nearly so. 
Figure 3

Trade Weighted Real Exchange Rate

Index $(1973: 3=100)$

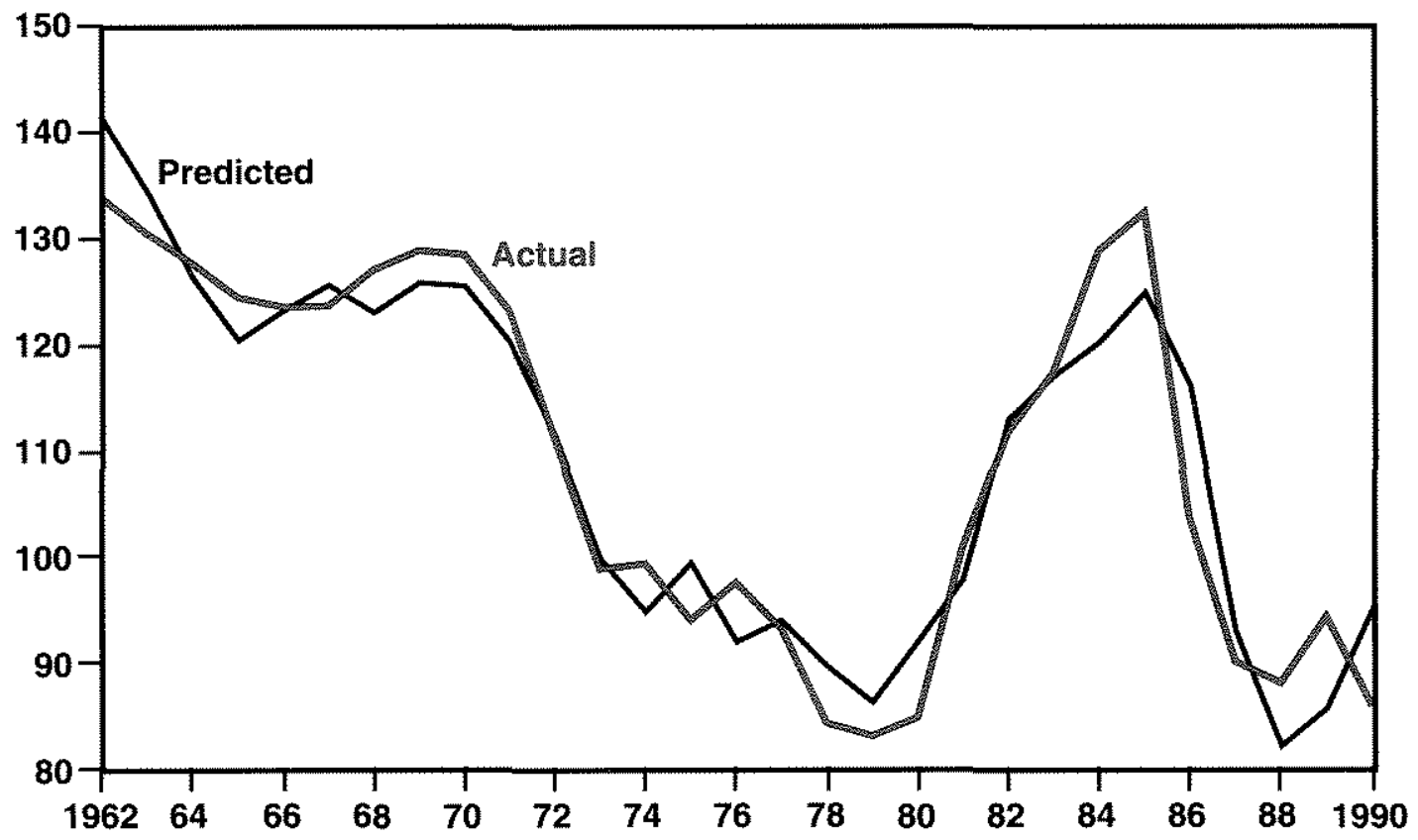

The dependent variable in the regressions reported in the first and third columns of figtre 3 is the average made-weighted real exchange for the period. The fourth and fifth columns repeat the regressions for annual data using the monthly average value for December as the dependent variable. The results are similar.

The estimates in table 3 permit a test of the unit coefficient on $R E R_{1-1}$ implied by the randomwalk hypothesis. All of the estimates are below unity, but two are not significantly different from unity; these are in the first and second columns of table 3 . The estimates in the third and fifth columns differ from unity by more than two standard errors, so they reject this central implication of the random walk.

Recent work on the causes of fluctuations emphasizes the importance of real shocks to aggregate supply as a cause of fluctuations. The effects on the real exchange rate of the rise and fall of the relative price of oil in the $1970 \mathrm{~s}$ and $1980 \mathrm{~s}$ is an obvious candidate for investigation. The relative price of oil can be included in equation (2) as an additional variable affecting the permanent component of the real exchange rate. Annual data for $1972-90$ and $1962-90$ reject the elfect; the coefficient of the relative oil price is small $(-0.03)$ in each period and has a standard erros largen than the estimated coefficient.

The use of real money balances combines the separate eflects of money and prices. To separate the effect of policy actions from the effects of prices, I first differentiate $m_{1}=\left(M_{1} / p\right)$ then lag the denominator by one period to get

(4) $d m_{1}=\frac{d M_{1}}{p_{1-\mathrm{k}}}-\frac{d p_{t}}{p_{1-1}}\left(\frac{\mathrm{M}}{p_{1-1}}\right)$

The first term is the real value (in past prices) of the current change in nominal balances. The second is the revenue from the intlation tax on last period's real money balances. To estimate responses to these variables, I take first differ. ences of equation (3) using equation (4) to replace dm.

Table 4 shows estimates relating the annual change in the real exchange rate to changes in some policy variables and real shocks. I have onitted the change in $m^{*}$ to conserve a degree of freedom. $\Delta \mathrm{m}^{*}$ typically has a small negative coefficient and is not significant. Changes in money and changes in defense spending relative 


\section{Table 4}

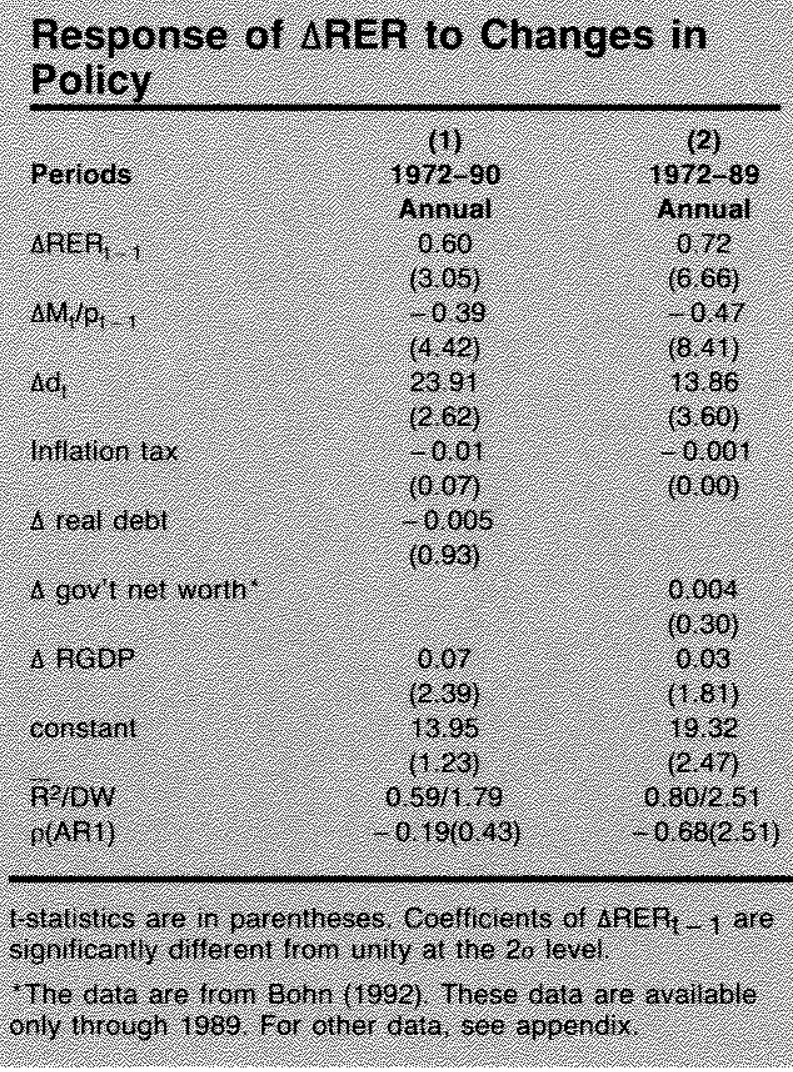

to GDP have considerable effect. For example a 0.1 percentage point change in the share of defense spending changes the real exchange rate between 1.4 percentage points and 2.4 percentage points based on the two equations. The 1982 increase in defense spending alone appreciated the dollar by 8.7 percentage points using the coefficient estimate for $1972-89 .^{\mathrm{t} 2}$

The inflation tax is not significant in the regression or in alternative estimates. This is unsatisfactory. Without a significant response to inflation, the equations imply that a change in nominal money has a permanent effect on the real exchange rate. If the equations are interpreted as short-term responses, they leave an important part of the dynamics unspecified.

Much recent discussion of the appreciation of the real exchange rate in the early 1980 s, following the Reagan tax cuts, linked the appreciation either to the budget deficit or to the increased after-tax return to real capital. The change in the real value of government debt measures the part of the current federal budget deficit financed by borrowing. I used the change in real GDP (RGDP) as a measure of the real return to real capital. This variable also captures the effects of changes in real output emphasized in the business cycle literature. Because real output is close to a random wak, changes in RGDP are a measure of unanticipated changes.

The change in RGDP has a significant effect on the change in the real exchange rate. The size of the coefficient is misleading because the changes are in billions of dollars. A more suggestive comparison is given by the change in the real exchange rate induced by changes in RGDP and the defense spending rates during four years of appreciation-1981-84. The total appreciation of the real exchange rate for this period is 44 . The coefficients in the first column of table 4 assign slightly less than half of this change to the change in the defense spending ratio and slightly more than half to the change in RGDP. These calculations neglect other variables, particularly changes in money and lags of the real exchange rate. And the calculation overstates the importance of supply shocks or changes in tax rates because the changes in RGDP include the recovery from the 1981-82 recession that would have occurred in the absence of tax changes or supply shocks.

The response to deficit finance, measured by the change in real government debt, is small and insignificant. A problem with testing for effects of the budget deficit is the incomplete and imprecise way in which the deficit is measured. Eisner and Pieper (1984) called attention to this problem and showed that there are large differences between current accounting measures and measures of a more economically relevant magnitude. Bohn (1992) computed a measure of government net worth that includes principal government assets and liabilities other than social Security and Medicare liabilities. The second column substitutes the change in real government net worth from Bohn for the change in the real value of the federal debt as a measure of the deficit. Government's net worth is nega tive, and if properly measured, the level of government net worth is the value of future tax payments. Changes in net worth have no significant effect. The responses to changes in RGDP and changes in the defense spending share both fall. Each explains a smaller fraction of the 
Figure 4

Annual Changes in Real Exchange Rates

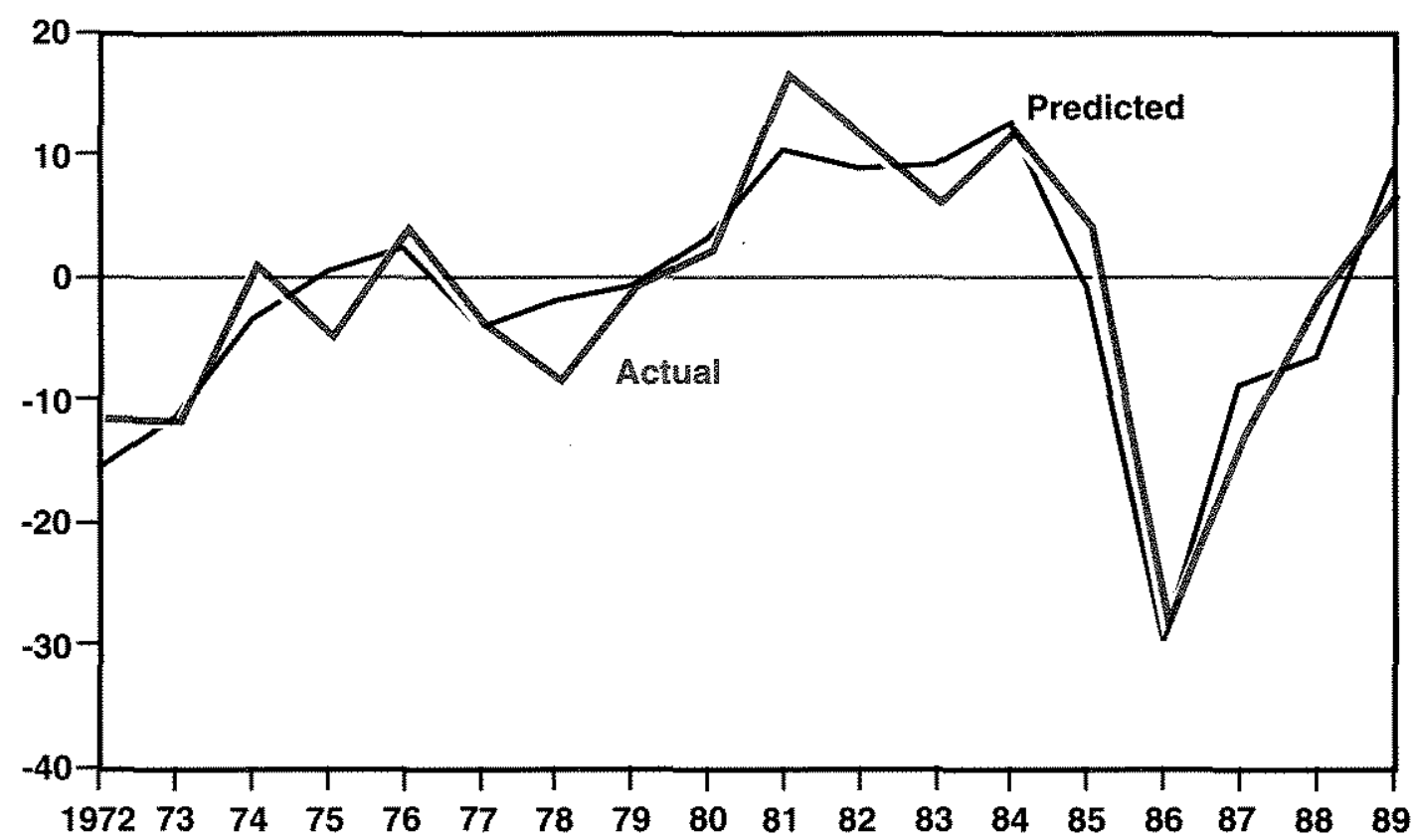

change in the real exchange rate during 1981 to 1984 (and other periods). The implied change in the real exchange rate resulting from changes in $I R G D P$ and the defense spending share are now approximately 25 percent and 29 percent respectively.

Figure 4 shows predicted and actual changes in the real exchange rate based on the estimates in the second column of lable 4 . Inspection suggests that the equation explains the annual changes more accurately for the 1980 s than for the 1970 s. This is particularly true in 1974 and 1975. There are only three years in which actual and predicted changes go in opposite directions-1975, 1978 and 1983 . Actual and predicted changes move together during the appreciation and subsequent depreciation of the dollar in the 1980 s. The equation suggests that contemporaneous changes in money and in defense spending are the principal factors keeping the predicted changes in step with actual changes.

\section{WMTTATONS}

The empirical results are subject to some limiLations. This section briefly discusses some problems arising from the absence of a structural model, neglect of simultaneity, and problems of stationarity.

First, the estimates are obtained from a simple model of permanent and transitory changes, not from a structural model. The equations are neither structural equations nor reduced forms of a structural model. An advantage of the model is that it nests the effects of money and defense spending within a popular statistical model, the random walk.

Second, several of the variables such as the price level, output, the real value of money and the defense spending share are simultaneously determined. Simulaneity has been neglected throughout. The changes reported in lable 4 and the use of lagged prices removes some of these problems. That the principal results are unaffected suggests that simultaneity may not impart serious bias to the estimates in table 3

Third, many studies of exchange rates have investigaled the stationarity of exchange rates. Tests of non-stationarity at first seemed to support the hypothesis. More recent work using longer time series, however, casts doubt on this conclusion. Engel and Hamilion (1990) did not test for stationarity, but they found persistent 
departures from a random walk. Earlier, Krasker (1980) coined the term peso problem for persistent deviations of exchange rates in a particular direction. Papers by Huizinga (1987), Hakkio and Joines (1990), Lothian (1991), and Diebold, Husted, and Rush (1991) are part of the growing literature rejecting non-stationarity based on evidence that real exchange rates return to a mean value.

A main reason for the differences in findings between earlier and later studies is the use of a longer span of years. Some early studies used daily or monthly data to obtain a larger number of observations. Becent studies suggest that an increased number of high-frequency observations is a poor substitute for the relative paucily of low-frequency data. ${ }^{13}$

The principal conclusion to draw from many of the studies is that the real exchange rate is subject to persistent and transitory changes. Some changes in the real exchange rate persist for long periods. Some of the changes are reversed quickly. Diebold, Husted, and Bush (1991) conclude that on average the half-life of a shock to the real exchange rate has been about three years. This finding is similar to the decay rates implied by the coefficients on annual values of the lagged real exchange rate in table 3.

Inspection of figure 1 suggests that the multilateral real exchange rate remained within a range of $95 \pm 15$ from 1973 to 1980 and returned to approximately the same range in 1987. To test for stationarity, I used quarterly data for first quarter 1973 to fourth quarter 1990 but omitled the sharp appreciation and depreciation from third quarter 1980 to first quarter $1987 .^{14}$ 'The coefficient of the lagged multilateral real exchange rate on the change in the real exchange rate is 0.14 with a $t$-statistic of 2.72. The Dickey-Fuller test statistic is 2.93 at the 5 percent level and 2.60 at the 10 percent level. On this basis, I reject non-stationarity.

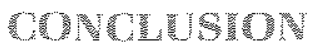

Milton Friedman's (1953) essay on flexible exchange rates anticipated much of the discussion and many of the controversies of the next 40 years. Friedman did not claim that flexible exchange rates would be stable rates. Stability depends on the size and frequency of shocks. Friedman claimed that flexible exchange rates would (1) contribute to trade liberalization, (2) avoid reliance on direct controls, (3) facilitate rearmament and (4) allow countries to follow domestic policies to achieve price stability.

Several of these conjectures were correct. Direct controls on capifal movements have been reduced since 1973 in all developed countries and in some developing countries. It seems likely that rearmament (defense spending) would have provoked greater conflict about payments imbalances in the 1980 s under fixed exchange rates than under the system that prevailed. Flexible rates permitted countries to choose how much of the stimulus emanating from the United States they wished to absorb. Many countries, indeed most developed countries, both purchased dollar securities and appreciated their currency.

The average rate of inflation has been brought down under flexible rates, and some countries have achieved price stability at times. Trade restrictions, however, increased in the 1980 s, particularly in the United States, and the movement toward trade liberalization slowed.

Friedman did not argue that exchange rates would be stable. He argued that the path followed by real exchange rates would depend on the real and monetary disturbances to which the economy is subject and on the persistence of shocks. Critics argued that destabilizing speculation and random movements dominate exchange rate changes and create an excess burden. This burden, some suggested, could be reduced by fixing exchange rates or establishing target zones.

The paper does not address the issue of excess burden. However, I compare variability of output and the terms of trade for four countries under the Bretton Woods system and the different regimes adopted after 1973. There is no evidence that real output is generally more variable under flexible exchange rates. Terms of trade are more variable after 1973 , but the data do not suggest that the increased variability is mainly the result of the exchange rate regime.

Further, I compare levels and changes in real exchange rates to the values predicted by a model.

13Hakkio and Rush (1991) reach the same conclusion based on more formal lests.

${ }^{14}$ The hypothesis implies and the data suggest that the appreciation and depreciation in this period is mainly the result of policy action. 
The forecast errors do not give evidence of large, persistent errors. On the contrary, the models call the turning points in the level and changes in the exchange rate with considerable accuracy. The data suggest, however, that there is more unexplained variability of real exchange rates after 1973 than before whon measured by the standard error of estimate for the regression equation.

The evidence also suggests that much of the movement in both levels and changes in annual values of the U.S. multilateral real exchange rate is explained by permanent or persistent changes in a few variables. The principal variables are real money balances and the share of defense spending in GDP. When the change in real balances is separated into variables measuring the current change in nominal money and the current change in the price level, the data suggest that the change in nominal money (measured at past prices) has a more important short-run effect. Quarterly data on levels of the variables support the principal findings.

Monetary and fiscal variables are nested with in a random walk model of the real exchange rate. If the random-walk component dominated the exchange rate, the data would reject the relevance of the monetary and fiscal variables. The tests based on annual and quarterly data and on anmual changes support the opposite conchusion: monetary and fiscal effects are persistent and reliable, and their effect is contemporaneous-m within the current year or quarter. Of course, none of the findings here deny that the random walk maty dominate levels or changes of the exchange rate at higher frequencies.

Two principal observations about fuctuating exchange rates during the past 20 years are: (1) the close relation between real and nominal exchange rates and (2) the sharp appreciation and subsequent depreeiation of the real dollar exchange rate in the 1980s. I conjecture that the principat reason for the correspondence between movements in rea and nominal $e x$. change rates is that real exclange rates are driven by contemporaneous permanent changes in real variables, particularly peal defense spend. ing and real money balances, whereas nominal exchange rates are driven by the nominal val. ues of the same variables. Much of the shortterm effect of money on the real exchange rate appears to be the result of changes in nominal money, so it would not be surpeising to find that changes in nominal money balances have a significant effect on the nominal exchange rate also.

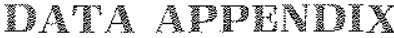

Nominal exchange rate (FNER): Index of the trade-weighted foreign exchange value of the United States dollar compiled by the Federal Reserve. The index is a geometric average of 10 industrialized countries dolar value of their currencies weighted by their shares of world trade between the years 1972 and 1976 . The 10 countries are Gemany, Japan, France, United Kingdom, Canada, Italy, Netherlands, Belgium, Sweden and Switzerland.

Trade-weighted price level (TwCPl): Geometric average of 10 industrialized countries' consumer price indexes weighted by their shares of total world trade.

Real exchange rate: FNER deflated by the ratio of the United States consumer price index (CPI) to the 10 countries' trade-weighted CPI.

Real money balances ( $m$ ): United States M1 monelary aggregate deflated by the United States CPI.

Defense spending share (d): Ratio of the United Stales defense spending in current dollars to GDP in current dollars.

Foreign money balances (TWNM): Arithmetic average of indexes of $\mathrm{M} 2$ monetary aggregates of Canada, Germany, Great Britain, and Japan (M2 \& CD), weighted by their shares of total world trade between the years 1972 and 1976 . Foreign real money balances: TWNM deflated by TWCPL.

Real government net worth: Real government deficit measured by the US government real net worth from Bohn (1992).

Relative price of oil: Oil price measured by composite refiners' acquisition cost deflated by GNP deflator.

Real federal debt: Gross federal debt net of Federat Reserve holdings deflated by the C.PI.

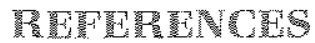

Ajiber, Robert Z. "The Case for Flexible Exchange Rates Revisited," University of Chicago (unpublished).

Becketti, S., and Hakkio, C. "How Real is the 'Real Exchange Rate?" draft Federal Reserve Bank of Kansas City (April).

Bohn, H. "Budget Deficits and Government Accounting," Carnegie Rochester Conference Series on Public Policy (December 1992), pp. 1-83.

Chinn, M. "Some Linear and Nonlinear Thoughts on Exchange Rates," Journal of International Money and Finance (June 1991), pp. 214-30.

Diebold, F.X., Husted, S., and Rush, M. "Real Exchange Pates under the Gold Standard," Journal of Political Economy (December 1991), pp. 1252-71. 
Edwards, S. Real Exchange Rates, Devaluation, and Adjustment: Exchange Rate Policy in Developing Countries (MIT Press, 1989)

Eisner, R. and Pieper, P. "A New View of the Federal Debt and Budget Deftcits," American Economic Review (March 1984), pp. $11-29$.

Engel, $C$, and Hamilton, J.D. "Long Swings in the Doltar: Are They in the Data and Do Markets Know It?" American Economic Review (September 1990), pp. 689-713.

Frenkel, J. "Turbulence in the Foreign Exchange Markets and Macroeconomic Policies," in L. Melamed, ed., The Merits of Flexible Exchange Rates (George Mason University Press, 1988), pp. 445-69.

Friedman, M. "The Case for Flexible Exchange Rates," in Friedman, M., ed., Essays in Positive Economics (University of Chicago Press, 1953).

Haberler, G. "The International Monetary System and Proposals for International Policy Coordination," in Cagan, P., ed., Contemporary Economic Problems (American Enterprise Institute, 1987), pp. 63-96.

Hakkio, C. and Joines, D. "Real and Nominal Exchange Rates Since 1919," working paper, Federal Reserve Bank of Kansas Ciły (September 1990).

Hakkio, $C$. and Rush, M. "Cointegration: How Short is the Long Run?" Journal of International Money and Finance (December 1991), pp. 571-8ћ.

Huizinga, J. "An Empirical Investigation of the Long-run Behavior of Real Exchange Rates," Carnegie Rochester Conference Series on Public Policy (Autumn 1987), pp. $149-214$
Krasker, W. "The 'Peso Problem' in Testing the Efficiency of Forward Exchange Markess," Joumal of Monetary Economics (April 1980), pp. $269-76$.

Krugman, P., and Miler, M. "Why Have a Target Zone?" Carnegie Rochester Conference Series on Public Policy (forthcoming).

Lothian, J. "A History of Yen Exchange Rates," in W.T. Ziemba, W. Baitey, and $Y$. Hamao, eds., Japanese Financial Market Research (Elsevier, 1991).

Meese, $R$. and Rogoff, K. "Empirical Exchange Rate Models of the Severties: Do They Fit Out of Sample?" Journal of international Economics (Februafy 1983), pp. 3-24.

Meltzer. A.H. "Size, Persistence and Interrelation of Nominal and Real Shocks," Joumal of Monetary Economics (January 1986), pp. 161-94.

"Some Empirical Findings on Differences Between EMS and Non-EMS Regimes," Cato Journal (Fall 1990), pp. $455-83$.

Mussa, M. "Nominal Exchange Rate Regimes and the Behavior of Real Exchange Rates: Evidence and Implications," Carnegie Rochester Conference Series on Public Folicy (Autumn 1986), pp. 117-213.

Singleton, K. "Speculation and the Volatility of Foreign Currency Exchange Rates." Camegie Rochester Conference Series on Public Policy (Spring 1987), pp. 9-56.

Wallich, $\mathrm{H}$, "Floating as Seen from the Central Bank," in $\mathrm{L}$. Melamed, ed., The Merits of Flexible Exchange Rates (George Mason University Press, 1988), pp. 395-403. 